\title{
IL2RA wt Allele
}

National Cancer Institute

\section{Source}

National Cancer Institute. IL2RA wt Allele. NCI Thesaurus. Code C51362.

Human IL2RA wild-type allele is located within 10p15-p14 and is approximately $51 \mathrm{~kb}$ in length. This allele, which encodes interleukin-2 receptor alpha chain protein, plays a role in clathrin-independent endocytosis, cytokine activation and immune functions. 